\title{
Role-Play: Taking the Line of Least Resistance
}

\author{
Dr. Mohamad Jafre Zainol Abidin \\ School of Educational Studies, University of Science Malaysia (USM) \\ 11800 Penang, Malaysia \\ Siti Rafizah Fatimah Osman \\ School of Educational Studies, University of Science Malaysia (USM) \\ 11800 Penang, Malaysia \\ MoniroSadat Hosseini \\ School of Educational Studies, University of Science Malaysia (USM) \\ 11800 Penang, Malaysia
}

Accepted: March 5, 2012 Published: April 21, 2012

Doi:10.5296/ijld.v2i2.1424 URL: http://dx.doi.org/10.5296/ijld.v2i2.1424

\begin{abstract}
Today, one of the main concerns in second language acquisition is to learn how to communicate orally with others. So speaking has played an increasingly essential role in second language settings. However, in many universities, ESL students rarely communicate effectively in English with other people. They would rather remain passive when a communicative task is assigned. Such a phenomenon has long left many ESL practitioners defeated. This had prompted the research to ascertain the effectiveness of role-play in eradicating the problem. Using Kolb (1984) model in the ESL classroom experimentally, after fourteen weeks, the outcomes showed that role-play is an effective technique to enhance the learners' confidence and their oral competency.
\end{abstract}

Key words: role-play; ESL students; oral competency. 


\section{Introduction}

The need for communicative skills in English has been increasing in everyday situations as well as work situations ( Shen \& Suwanthep, 2011). The English Language Syllabus, for many years, has emphasized on the need to equip students with the ability to communicate orally. However, being orally competent in the second language has always been a far-fetched dream among most of the students.

Many Malaysian students entering universities suffer from the lack of English proficiency and self-confidence in communicating in English. Most of them have good ability in writing in English but their conversational skills are awful.

In this case, Shen and Suwanthep (201, cited from Hu, 1988 \& Weng, 1996) described such students as "dumb English." "Dumb English" refers to the situation when students want or need to communicate in English but they cannot perform the task successfully due to such possible reasons as tension, shyness and/or lack of confidence and effective communication skills in English (Wang \& Motteram, 2006). Therefore, learners need classroom tasks in which they can develop skills to participate in communicative interactions. Although many teachers try to help students become more confident in interacting with the target language, the problem of students lacking in oral communicative competence remains a challenge nationwide. To eradicate the problem, the root cause of such issue had to be identified and ways and alternatives to resolve it should be found.

In fact, the teacher has the responsibility to create a condition in which he or she teaches the oral skills of the target language enthusiastically so that students can take part in communicative tasks actively and gregariously. Moreover, there are efforts to focus more on learners and learning rather than teachers and teaching in ESL contexts, and this led to more attention to development of communicative competence in second language acquisition.

However, it is not enough to provide students with only opportunities to speak in English; they must also be stimulated to speak in different situations, which may help them to speak with confidence. The ideal issue would be to participate in different communicative interactions and carry out different tasks. Nonetheless, enacting those situations in a classroom serves the second-best alternative. Activities such as simulation and role-play will encourage students to think creatively as to how they can make role-play an enjoyable and fun activity in the class. In addition, they can develop their communicative and behavioural skills, as they need to interact and negotiate with others and practise the target language, which in turn will provide an avenue for motivation and involvement in learning contexts.

In this study, the cycles of learning which each student need to go through when being involved in role-play was Kolb's (1984) Experiential Learning Cycle - "learning by doing." It allowed student to be actively involved in the role-play activity, reflect on it, and expand on what have been reflected and conceptualised in learning contexts.

\section{Role-play Activity}

Larsen-Freeman (1986) explains that role-play is important because it gives learners an opportunity to practise communication in different social contexts and different social roles. It hopes that role-play done in pairs or groups, which requires learners to negotiate on meaning during the discussion as well as during the presentation, will give room to them to 
heighten their three facets of self-concept and aid the development of their communicative ability.

Role-play is a useful activity that can be utilized to help students with their L2 learning (Bartley, 2002). Furthermore, constructive role-plays make students become more interested and get involved in classroom learning not only in terms of the teaching material, but also in terms of integrating the knowledge learned in action (Brown \& Yule, 1995).

Role-play activities provide a wealth of vocabulary and Williams (2004) discusses how this verbal aspect helps children to "develop communicative competence" through the need to listening and responding. Cast (2007) also mentions the atmosphere generated, going on to observe how when actively involved in role-play, the children are able to experience both independent and collaborative learning.

According to Uzun (2009) the main inspirational idea of role-play is that students feel better, get less tired and become more motivated when they enjoy doing things in the class environment, such as playing games, (cited in Bakar, Tuzun \& Cagiltay, 2008; Sahhuseyinoglu, 2007; Bayirtepe \& Tuzun, 2007; Tuzun, 2006). He believes that the aim of education should be teaching or learning more, or better to say qualitatively, rather than just quantitatively.

\section{Low Self-concept and Resistance to Communication}

Self-concept can be classified into three categories. As viewed by Rosenberg (1979), these are (a) how you view your competence or ability, (b) how you see yourself with others, and (c) how you feel when being with others. However, many students are handicapped and apprehensive about communication or have indifferent attitude towards communication. Such negative view may pose a barrier to the students and affect their participation in ESL communicative tasks.

As for the students of UiTM, there are several reasons why they may not have the interest to participate in role-play activities and would rather remain passive. Despite their homogenous cultural beliefs and practices, the disparity in the socio economic background may make them feel inadequate and inferior. Some other reasons can be childhood experiences that do not enhance positive self-concepts, lack of positive reinforcement, love and support from significant others (parents, teachers, and friends) which led to a feeling of incapability and insecurity.

Furthermore, the majority of students in UiTM are aged between 18 and 22 years old. At this range of age, they are very conscious of themselves, not only in relation to the opposite sex, but also to those of the same gender group. The transition between adolescence and adulthood may cause feelings of extreme shyness when participating in class or group tasks, thus affecting their self-concepts (Naginder, 1999).

\section{Poor Communication or Oral Competence}

The majority of UiTM students have always been commented as having problems to transmit their messages across orally. The evidence to such claim are shown in the statistics in table 1-3 which show how learners of BEL100, BEL200 and BEL250 of Semesters November 2001 to April 2002 and May 2002 to October 2002 in UiTM Perlis fared in their speaking test. 
The statistics show that most of the UiTM, Perlis students are not competent enough to speak fluently in real situations. Very few have actually reached the stage of being excellent in communication. Most of them were clustered within two bands: fair and good, far from being competent. A few lecturers lamented that most of the students who fared badly and fairly in the test were not confident enough about themselves and also lack in the command of the language. This, then, resulted in low scoring in the three aspects looked into: task fulfilment, language, and communicative ability. Their insufficient proficiency has hindered their ability to put forth the message well.

Table 1: The Statistics of BEL100 Speaking Scores

\begin{tabular}{|l|c|c|c|c|c|c|c|}
\hline Semester/Scores & $\begin{array}{l}\text { Poor } \\
\mathbf{1 - 4}\end{array}$ & $\boldsymbol{\%}$ & $\begin{array}{l}\text { Fair } \\
\mathbf{4 . 5 - 7 . 5}\end{array}$ & $\boldsymbol{\%}$ & $\begin{array}{l}\text { Excellent } \\
\mathbf{8 - 1 0}\end{array}$ & $\mathbf{\%}$ & total \\
\hline $\begin{array}{l}\text { December } \\
\text { 2001-April 2002 }\end{array}$ & 10 & $\mathbf{2 . 8 2}$ & 355 & $\mathbf{7 6 . 5 1}$ & 99 & $\mathbf{2 1 . 3 4}$ & 64 \\
\hline $\begin{array}{l}\text { May2002- } \\
\text { October 2002 }\end{array}$ & 9 & $\mathbf{1 . 8 7}$ & 400 & $\mathbf{8 3 . 1 6}$ & 72 & $\mathbf{4 . 9 7}$ & 81 \\
\hline
\end{tabular}

Source: The Academy of Language Studies, Universiti Teknologi Mara Perlis

Table 2: The Statistics of BEL200 Speaking Scores

\begin{tabular}{|l|c|c|c|c|c|c|c|c|c|c|c|}
\hline $\begin{array}{l}\text { Semester } \\
\text { / Scores }\end{array}$ & $\begin{array}{l}\text { Very } \\
\text { Poor } \\
\mathbf{1 - 3}\end{array}$ & $\mathbf{\%}$ & $\begin{array}{l}\text { Poor } \\
\mathbf{4 - 6}\end{array}$ & $\mathbf{\%}$ & $\begin{array}{l}\text { Fair } \\
\mathbf{7 - 9}\end{array}$ & $\boldsymbol{\%}$ & $\begin{array}{l}\text { Good } \\
\mathbf{1 0 - 1 2}\end{array}$ & $\boldsymbol{\%}$ & $\begin{array}{l}\text { Excell } \\
\text { ent } \\
\mathbf{1 3 - 1 5}\end{array}$ & $\mathbf{\%}$ & Total \\
\hline $\begin{array}{l}\text { Dec } \\
\text { 2001-Apr } \\
\mathbf{2 0 0 2}\end{array}$ & 10 & $\mathbf{1 . 2 3}$ & 107 & $\mathbf{1 3 . 1 3}$ & 370 & $\mathbf{4 5 . 3 9}$ & 245 & $\mathbf{3 0 . 0 6}$ & 85 & $\mathbf{1 0 . 1 8}$ & 817 \\
\hline $\begin{array}{l}\text { May-Oct } \\
\mathbf{2 0 0 2}\end{array}$ & 2 & $\mathbf{0 . 2 8}$ & 67 & $\mathbf{9 . 5 3}$ & 308 & 43.81 & 245 & $\mathbf{3 4 . 8 5}$ & 83 & $\mathbf{1 1 . 8 1}$ & 703 \\
\hline
\end{tabular}

Source: The Academy of Language Studies, Universiti Teknologi Mara Perlis

Table 3: The Statistics of BEL250 Speaking Scores

\begin{tabular}{|l|c|c|c|c|c|c|c|c|c|c|c|}
\hline $\begin{array}{l}\text { Semest } \\
\text { er/ } \\
\text { Scores }\end{array}$ & $\begin{array}{c}\text { Very } \\
\text { Poor } \\
\mathbf{1 - 3}\end{array}$ & $\mathbf{\%}$ & $\begin{array}{c}\text { Poor } \\
\mathbf{4 - 6}\end{array}$ & $\boldsymbol{\%}$ & $\begin{array}{c}\text { Fair } \\
\mathbf{7 - 9}\end{array}$ & $\mathbf{\%}$ & $\begin{array}{c}\text { Good } \\
\mathbf{1 0 - 1 2}\end{array}$ & $\begin{array}{c}\text { Excellen } \\
\mathbf{t} \\
\mathbf{1 3 - 1 5}\end{array}$ & $\mathbf{\%}$ & Total \\
\hline $\begin{array}{l}\text { Nov } \\
\mathbf{2 0 0 1}- \\
\text { Apr } \\
\mathbf{2 0 0 2}\end{array}$ & 0 & $\mathbf{0}$ & 60 & $\mathbf{1 1 . 0 1}$ & 257 & $\mathbf{4 7 . 1 6}$ & 218 & $\mathbf{4 0}$ & 10 & $\mathbf{1 . 8 3}$ & 545 \\
\hline $\begin{array}{l}\text { May - } \\
\text { Oct } \\
\mathbf{2 0 0 2}\end{array}$ & 2 & $\mathbf{0 . 2 9}$ & 39 & $\mathbf{5 . 6 9}$ & 235 & $\mathbf{3 4 . 3 1}$ & 357 & $\mathbf{5 2 . 1 2}$ & 52 & $\mathbf{7 . 5 9}$ & 685 \\
\hline
\end{tabular}




\section{Traditional Classroom Approach - Lacking in Learner Autonomy}

In Universiti Teknologi Mara (UiTM), role-play, which used to be a favourite activity employed by lecturers in the oral communication component, was regularly treated by teacher-fronted practice, as teachers tend to interfere with students' effort to generate the proper discourse or may even try to correct their pronunciation and enunciation. This interfering habit of the teacher made the learners reluctant to participate in the activity and withdraw themselves.

\subsection{Objectives of the Study}

The objectives of this study are:

1. to determine the effects of using the experiential form of role-play as a learning process on self-concept.

2. to determine the effects of using experiential form of role-play as a learning process on communicative competence.

In this study, the experiential learning process of role-play, which gives autonomy to learners, is the learning platform for students. Therefore, this study investigated whether the opportunity to learn through the experiential learning and learner-centred process weekly (continually) can enhance the self-concept and communicative skills of the students.

\section{Related Literature}

Naginder (1999) carried out a two-week case study with a group of Pre-Commerce students of Institut Teknologi Mara Perlis Branch. The aim of her study was to find out how far students' self-concept might influence their participation in the experimental learning process of role-play and the extent of self-concept enhancement as a result of role-play activities. After the experimentation was completed, she managed to reveal a positive relationship between self-concept and students' participation in role-play. This was evident from several indicators such as prolonged nervousness, language proficiency, peer influence, and role of the teacher while progress came in the form of reduced anxiety, adaptability to the task, and awareness of own strengths, and the like.

Krish (2000) carried out a role-play activity with a class of 15 distance learners of Universiti Kebangsaan Malaysia with the aim of enabling them to cope with language requirements in the academic and work environment. For this tertiary level class, she used newspaper reports on Japanese Encephalitis outbreak, which was collected over a period of time. It included the views of the farmers, medical experts, consumers' rights and feelings of the affected residents. This particular issue was chosen because it provided learning opportunities for the learners to practise in a real-life situation. Being an experiential learning process, a feedback session was held to gather responses on their participation for the learners to develop awareness and confidence in their learning strategies and communicative ability. The outcomes were that they helped one another to decide who should speak, and prompted each other with ideas to get the play going. They claimed to have gained confidence 
and start interacting more in the forms of posing enquiries as well as responding to questions. The strong points noted by Krish are that such activity helps increase communication skills and participation, change the attitudes towards language learning, and above all provide realistic chances for them to interact with others in the classroom.

Shrum and Glisan (2000) claimed that during the preparation for role-play, students benefit from well-organised instructions and guidance, such as a model situation and hints concerning vocabulary and grammar use.

Grant and Mistry (2010) have done a research on the effect of role-play in ESL pupils' language proficiency in England. The results of their study showed that role-play activity can be helpful to improve ESL students' communicative ability, in that it helps them feel relaxed when practicing words and phrases. Their findings suggest that specific training for staffs is necessary to provide them strategies for teaching the very varied mixture of language needs and abilities.

Shen and Suwanthep (2011) recently have conducted a study investigating the implementation of constructive role-plays via NHCE e-learning and its effect on Chinese EFL learners' communicative ability in college English classes. The results of their study showed that while students express positive opinions towards implementation of e-learning constructive role-plays, it has positive effects on the improvement of their speaking in terms of production and language fluency.

\section{Research Design}

The research design was quasi-experimental, adopting the Pre test and Post test Experimental and Control Group Design. As for the experimental group, the treatment was the experiential form of role-play, while the control group was given the traditional teacher-fronted approach. The study was quantitative, and data was collected through the implementation of pre test and post test of BEL200 speaking test and the use of the Multi dimensional Test of Self-concept (MTS).

\section{Population Sample}

The respondents of this study were 59 students studying in Universiti Teknologi Mara (UiTM) - two groups of second semester Diploma in Science. Most of these students faced anxiety and were not confident enough to speak in English. The subjects selected were 32 students for the control group (DIS 2B) and 27 students as the experimental group. The class schedule and the routines of the university as well as the students were not disrupted.

\section{Statistical Findings on Self-Concept}

The results of Findings on Self-concept based on the Multi dimensional Self-concept Test (Self-evaluated Self-concept) show that both the experimental and control groups underwent changes in self-concept between speaking pre test and post test. The assessment of self-concept of the respondents was done by using the MTS. The mean change of the experimental group $=13.7778$ exceeded the overall mean $=8.1389$. On the other hand, the control group, which registered a mean change $=2.5000$ recorded less change. The paired $t$-test results show whether the change with both groups is significant. 
The result of the test confirms that the change from a large gap to a smaller one was significant at a $p$-value $=0.003$, and this helps to explain that the possibility of the results being reached by chance is very little. The traditional teacher fronted approach had not managed to narrow the gap significantly at the $p$-value $=0.221$. In other words, there was very little likelihood for the change to have occurred because of the approach, and the outcome or reduction between pre test and post test might have been derived due to other extraneous factors and not the approach adopted.

\section{Lecturer-evaluated Self-concept}

The results in Table 4 show that both the experimental and control groups underwent changes in self-concept when performing individual task. The mean change obtained by the experimental group $=0.7593$ exceeded the overall mean $=0.3718$ as well as that of the control group's $=-.0157$. In fact, the change experienced by the control group went in the negative direction.

Table 4: Findings on Learners' Self-concept - Individual Task

\begin{tabular}{lllll} 
& & $\begin{array}{l}\text { Individual } \\
\text { Self-concept } \\
\text { (Pre test) }\end{array}$ & $\begin{array}{l}\text { Individual } \\
\text { Self-concept } \\
\text { (Post test) }\end{array}$ & $\begin{array}{l}\text { Change in mean } \\
\text { (Post pre) }\end{array}$ \\
\hline Experimental & $\mathbf{N}$ & 27 & 27 & \\
\cline { 2 - 5 } & Mean & 7.6481 & 8.4074 & $\mathbf{0 . 7 5 9 3}$ \\
\cline { 2 - 5 } Control & Std Deviation & 1.75310 & 1.43471 & \\
& $\mathbf{N}$ & 32 & 32 & $\mathbf{- 0 . 0 1 5 7}$ \\
\hline \multirow{2}{*}{ Total } & Mean & 7.4063 & 7.3906 & \\
& Std Deviation & 1.85106 & 1.39547 & \\
& $\mathbf{N}$ & 59 & 59 & $\mathbf{0 . 3 7 1 8}$ \\
\cline { 2 - 5 } & Mean & 7.5272 & 7.8990 & \\
\cline { 2 - 5 } & Std Deviation & 1.80208 & 1.41509 & \\
\end{tabular}

When assessed by the researcher on their self-concept during their performance of individual task, the respondents recorded a change of 0.7593 . The raise was confirmed significant as the $p$-value $=0.007$ is much lower than the accepted significant $p$-value $\leq 0.05$.

Even though the control group recorded a change of -0.0157 , it is not significant because the $p$-value was big $=0.956$. Therefore, it was very unlikely that the group when performing the individual task have experienced a change in self-concept. Such change might have occurred by chance as the teachers interpreted the learners' reactions from what they saw.

The outcomes in Table 5 reveal that the experimental group registered bigger change than the control group. The mean of change $=0.4630$ experienced by the experimental group was bigger than -0.0781 that of the control group and also the average mean $=0.1924$. It was clear that the experimental group recorded a change which exceeded the average by 0.2706 . 
Table 5: Findings on Learners' Self-concept-Group Task

\begin{tabular}{|c|c|c|c|c|}
\hline STATUS & & $\begin{array}{l}\text { Group } \\
\text { Self-concept } \\
\text { (Pre test) }\end{array}$ & $\begin{array}{l}\text { Group } \\
\text { Self-concept } \\
\text { (Post test) }\end{array}$ & $\begin{array}{l}\text { Change in mean } \\
\text { (Post pre) }\end{array}$ \\
\hline \multirow{3}{*}{ Experimental } & $\mathbf{N}$ & 27 & 27 & \\
\hline & Mean & 8.5185 & 8.9815 & 0.4630 \\
\hline & Std Deviation & 2.20786 & 1.21276 & \\
\hline \multirow{3}{*}{ Control } & $\mathbf{N}$ & 32 & 32 & \\
\hline & Mean & 8.1406 & 8.0625 & -0.0781 \\
\hline & Std Deviation & 2.28683 & 2.01906 & \\
\hline \multirow[t]{3}{*}{ Total } & $\mathbf{N}$ & 59 & 59 & \\
\hline & Mean & 8.3296 & 8.5220 & 0.1924 \\
\hline & Std Deviation & 2.2473 & 1.6159 & \\
\hline
\end{tabular}

\section{Experimental Group}

However, when evaluated on the group task, the change $=0.4630$ recorded with self-concept failed to confirm its significance since the $p$-value $=0.245$ was much bigger than the accepted $p$-value $\leq 0.05$.

\section{Control Group}

The control group when assessed during their performance of group task recorded a change of -0.0781 . Its big $p$-value $=0.801$ denied the significance of the change.

To sum up the outcome of both teaching modes on self-concept, it is evident that the study had yielded the answer sought by the research question about the effects of role-play on learners' self-concept. It is evident that role-play, the independent variable in this study, has proven to have affected learners' self-concept positively and significantly compared with the traditional teacher-fronted approach. Generally, students' self-concept underwent change but the improvement detected with the experimental group was far more significant and greater than the improvement of control group. Furthermore, the study also proves that role-play generally improved self-concept and did not degrade it.

The results show that both the experimental and control groups registered changes in oral competence when performing the individual task. However, the change experienced by the experimental group was bigger than that of the control group. This was proved by the mean difference $=1.3519$ which was higher than the overall mean 0.9152 , while the control group's increase $=0.5468$ was less than the overall difference.

\section{Experimental Group - Individual Task}

The mean difference $=1.3519$ reflects that the shift that the experimental group had undergone was significant. It means that there was a significant difference between the pre test result and the post test result as the $p$-value equaled 0.000 . 


\section{Control Group - Individual Task}

The mean difference $=0.5468$, shows that the post test result was higher than that of the pre test. The result was significant for the control group since the $p$-value equaled 0.019 .

The results show that both experimental and control groups registered changes in communicative (oral) competence at group level. The mean change of the experimental group $=1.1482$ was bigger than that of the control group $=0.7903$ which was smaller than the overall difference.

\section{Experimental Group - Group Task}

The mean difference for the group tasks undergone by the experimental group noted a change of 1.1482 and was confirmed significant by the $p$-value $=0.000$.

\section{Control Group -Group Task}

Undoubtedly, there was also a significant change in communicative competence with the control group although it was smaller than the overall percentage. The mean difference was 0.7903 while the $p$-value was 0.022 .

To conclude, both groups did experience change in oral competence after 10 weeks, yet the change recorded by the experimental group was far larger and more significant than that of the control group. Also, the statistical evidence of the significant gain mean of oral competence of the experimental group over the control group and percentage of change in raw scores were attributed to the positive effects of the experimental treatment variable continual or weekly practice of role-play. Thus, it answers the research question: whether role-play improves students' self-concept and communicative competence or not. In addition, the impact was much more significant and greater than the impact of traditional approach on the control group.

\section{Conclusion}

The aim of the present study was to find out the effectiveness of the implementation of experiential learning form of role-play of Kolb's (1984) Experiential Learning Cycle on learners' self-concept and their speaking ability and communicative strategies. The findings of this study indicated that the treatment group, which was assigned to role-play activity adopted in this study, showed significant improvement in their self-concept and communicative skills in comparison with the control group. This is because they encountered with the situations in which they should interact socially and negotiate with their peers and teachers intuitively. They had to negotiate and tolerate each other's views - the assignment of role to each group member, the plot, the turn-taking in giving opinions, the agreement and disagreement, the justification of opinions (social self-concept), being firm in projecting ideas and satisfactory voice control (academic self-concept), and displaying appropriate facial expression and eye contact (emotional self-concept). Moreover, their communicative competence was also at test. The grammaticality of the language in use (grammatical competence), use of gestures and fluency (strategic competence) and cohesiveness of ideas, and register used were also in examination. 


\section{Macrothink

On the whole, the experiential learning form of role-play had allowed learners more autonomy for them to decide on how to go about doing the role-play and gives them room to negotiate with one another and also to compliment the strengths and criticize the pitfalls constructively. Experience is the best teacher. If a real life experience is difficult or impossible, then an artificial environment, though not ideal, may be effective for learning (Fablusi, 2000). Furthermore, when past experiences can be applied directly to current experience, learning is facilitated (Brundage \& Mackeracher, 1980). Tomita (2008) discusses the pedagogical value that acting may provide. He claims that students can "recapture organic nature" by immersing themselves in the roles of other people. He explains that students concentrate on what they do, think, feel, and act in a dramatic order. This experience would help them to cultivate their mind and make them more creative. 


\section{References}

Bakar, A. et al. (2008). Students' Opinions of Educational Computer Game Utilization: A Social

Studies Course Case. H.U. Journal of Education, 35, 27-37.

Bartley, B. (2002). Role playing as a teaching strategy. Retrieved from http://condor.admin.ccny.cuny.edu

Bayirtepe, E. and Tuzun, H. (2007). The Effects Of Game-Based Learning Environments on Students' Achievement and Self-Efficacy in a Computer Course. H.U. Journal of Education, 33, 41-54.

Brown, G., \& Yule, G. (1995). Teaching the spoken language. Cambridge: Cambridge University Press.

Brundage, D.H. and Mackeracher, D. (1980). Adult learning principles and their application to program planning. Ontario: Ministry of Education.

Cast, J. 2007. Role-play in Key Stage 2. English 4-11, : 22

Chin,V.K. (2002, December 22). Jobless grads must not be choosy. The New Straits Times.

Dennison, B., and Kirk, R. (1990). Do, review, learn, apply: a simple guide to experiential learning. Oxford: Basil Blackwell.

Fablusi, J. (2000). Role-play simulation generator. Available at: http://www.fablusi.com

Foo, L. (2002, May 15). Make it compulsory. The New Straits Times.

Grant, K., \& Mistry, M.T. (2010). How does the use of role-play affect the learning of Year 4 children in a predominately EAL class? Journal of Education, 38, 155-164.

Haruyama, J. (2008). The Signifi cance of Drama in the Teaching of Foreign Languages: Through

the Activities of Drama and Language at the Tokyo University of Foreign Studies. Newsletter for International Association of Performing Language, 2, 14-18.

Hu, Z. L. (1988). Linguistics: A course book. Beijing: Beijing University Press.

Jones, Ken. (1988). Interactive learning events: a guide for facilitators. New York: Kogan Page Ltd. 
Naginder, K. (1999). Role play: The relationship between self-concept and learner participation in an experiential learning process. Unpublished master dissertation, USM, Pulau Pinang, Malaysia.

Kolb, D.C. (1988). Experiential learning: experience as the source of learning and development.

Englewood Cliffs, New Jersey: Prentice Hall.

Krish, P. (2001). A role play activity with distance learners in an English language classroom. Internet TESL Journal. 1-6

Larsen-Freeman, Diane. (1986). Techniques and principles in language teaching. Oxford: Oxford

University Press.

Rosenberg, M. (1979). Conceiving the self. New York. Basic Press.

Sahhuseyinoglu, D. (2007). Educational Games for Developing Critical Thinking Skills: Pre-

Service English Language Teachers' Views. Hacettepe University Journal of Education, 32, 266-273.

Shen, L. and Suwanthep, J (2011) . E-learning Constructive Role Plays for EFL Learners in China's Tertiary Education. Asian EFL Journal. Professional Teaching Articles, 49, $1-29$.

Shrum, J.L. and Glisan, E.W. (1994). Teacher's handbook: Contextualized language instruction.

Cambridge Mass: Harvard University Press.

Thornbury, S. (2005). How to teach speaking. London: Pearson Education Limited.

Tomita, H. (2008). Enjiru-koto no Kyouikuteki na Igi [Educational Value of Performing]. In M.

Tanigawa and T. Yanagihara (Eds.), Gekijo wo Sekaini: Gaikokugo Kyouiku no Rekishi to Chousen [Language Drama to the World: History and Challenge of Language Dramas]. Tokyo: Shinjuku Shobou.

Tuzun, H. (2006). Educational Computer Games and a Case: Quest Atlantis. Hacettepe University

Journal of Education, 30, 220-229.

Uzun, L. (2009). An evaluative checklist for computer games used for foreign language 
vocabulary learning and practice: Vocaword sample. Research on Youth and Language, Novitas Royal, 3(1), 45-59.

Wang, W., \& Motteram, G. (2006). CALL in China. IATEFL Voices, May-June(190), 7-8.

Weng, Q. F. (1996). English study strategies. Shanghai: Shanghai Foreign Language Education Press.

Williams, M. 2004. "Creative literacy: Learning in the early years". In Unlocking creativity: Teaching across the curriculum, Edited by: Fisher, R. and Williams, M. London: David Fulton Publishers Ltd.

Yang, T. T. (2002, May 15). Don't rush into teaching subjects in English. The New Straits Times.

Zarshik. (2002, May 15). Most can’t speak well. The New Straits Times. 